\title{
Preventive Measures for Family Vacation during COVID-19
}

Fauzunnasirah Fazil, Er Ah Choy, Habibah Ahmad, Susheel Joginder Singh, Noordeyana Tambi, Hamzah Jusoh

To Link this Article: http://dx.doi.org/10.6007/IJARBSS/v12-i1/12060

DOI:10.6007/IJARBSS/v12-i1/12060

Received: 05 November 2021, Revised: 08 December 2021, Accepted: 24 December 2021

Published Online: 15 January 2022

In-Text Citation: (Fazil et al., 2022)

To Cite this Article: Fazil, F., Choy, E. A., Ahmad, H., Singh, S. J., Tambi, N., \& Jusoh, H. (2022). Preventive Measures for Family Vacation during COVID-19. International Journal of Academic Research in Business and Social Sciences, 12(1), 1519-1533.

\section{Copyright: (c) 2022 The Author(s)}

\section{Published by Human Resource Management Academic Research Society (www.hrmars.com)}

This article is published under the Creative Commons Attribution (CC BY 4.0) license. Anyone may reproduce, distribute, translate and create derivative works of this article (for both commercial and non0-commercial purposes), subject to full attribution to the original publication and authors. The full terms of this license may be seen

at: http://creativecommons.org/licences/by/4.0/legalcode

Vol. 12, No. 1, 2022, Pg. 1519 - 1533

Full Terms \& Conditions of access and use can be found at http://hrmars.com/index.php/pages/detail/publication-ethics 


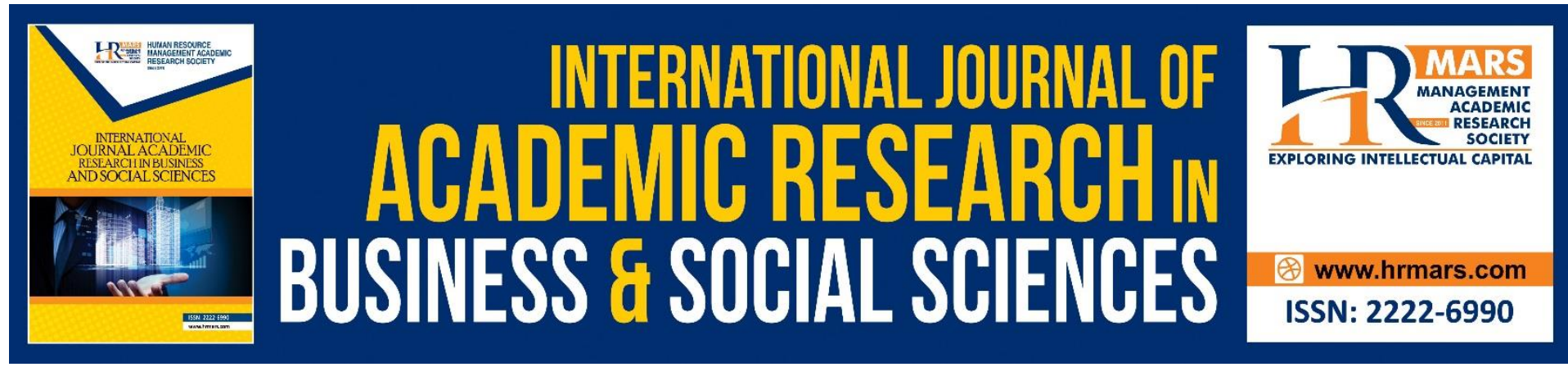

\title{
Preventive Measures for Family Vacation during COVID-19
}

\author{
Fauzunnasirah Fazil ${ }^{1,3}$, Er Ah Choy ${ }^{1}$, Habibah Ahmad ${ }^{1}$, \\ Susheel Joginder Singh ${ }^{2}$, Noordeyana Tambi ${ }^{1}$, Hamzah Jusoh ${ }^{1}$ \\ ${ }^{1}$ Centre for Research in Development, Social and Environment (SEEDS), Faculty of Social \\ Sciences and Humanities, Universiti Kebangsaan Malaysia, Bangi, Malaysia, ${ }^{2}$ Faculty of \\ Health Sciences, Universiti Kebangsaan Malaysia, Kuala Lumpur, Malaysia, ${ }^{3}$ Faculty of Hotel \\ and Tourism Management, Universiti Teknologi MARA, Melaka, Malaysia \\ Corresponding Author Email: eveer@ukm.edu.my
}

\begin{abstract}
COVID-19 severely impacted the tourism industry locally and globally. During the Recovery Movement Control Order (RMCO), the Malaysian government urged the people in the nation to take their family for vacation and to travel domestically to support the rejuvenation of the hotel sector. However, due to the harmful and contagious nature of COVID-19, the safety of the family members, especially the young and dependent children makes taking a vacation is fraught with uncertainty. Thus, this study sought to discover the safety procedures and associated actions taken by tourism providers with the implementation of the RMCO while concurrently combating and breaking the chain of infection. The objectives of the study are to investigate COVID-19 safety procedures in resuming tourism operation and to analyse the execution of safety procedures in family vacation consumption. The study covers the in-situ safety procedures experienced in family vacations during the COVID-19 pandemic at several popular family vacation destinations in Malaysia, which are located about a two-hour drive journey from the country's capital city. The results of the study present the preventive measures taken by local tourism providers in accordance with the guidelines provided by the local authorities. It is hoped that this study would contribute to existing knowledge on the preventive actions taken in facing the pandemic, specifically to the tourism field of education. Keywords: Tourism, Pandemic, Standard Operating Procedures, Safety, Lockdown.
\end{abstract}

\section{Introduction}

For the COVID 19 global pandemic, many countries have applied lockdown or movement control to stop or break the chain of the disease transmission. People were urged to stay at home and to be isolated. Studies have shown that past behavioural measures for the COVID19 pandemic through isolation via lockdown was applied in most countries as the preventive action to limit the spread and to break the chain of the virus transmission (Albzeirat et al., 2020). This includes Malaysia, which was among the first country in Southeast Asia to implement the movement control (Khor et al., 2020). 
The government of Malaysia announced six weeks of the enforcement of the movement control order (MCO) throughout Malaysia, commencing from March 18, 2020. The initial control order was superseded by the conditional movement control order (CMCO) that begun on May 4, 2020 with some relaxations in the rules. However, most sectors remained temporarily closed during this period, which includes the tourism sector. The tourism sector breathed a sigh of relief when the government proclaimed the reopening of the sector in the recovery movement control order (RMCO) phase, starting from June 10 to December 31, 2020 (Prime Minister Office of Malaysia, 2020).

The impacts of the MCO have affected operational disruption, supply chain disruption, future business direction and financial problems (Che Omar et al., 2020). In the RMCO, the government encourages Malaysians to take their families for a vacation domestically to support the local economic recovery plan. For some families, it is with mixed feeling taking their family out-of-home to stay at a hotel or tourism accommodation during the vacation. The nature of COVID-19 contagiousness is very difficult to be discerned as the symptom may not appear at an early infection phase in a number of cases. This situation leads to travel anxiety, especially in families with young and dependent children. As COVID-19 pandemic is novel and has never been experienced before, the safety protocols in covid prevention for family vacation are uppermost in the minds of the vacationers. Thus, the current study is intended to investigate:

- COVID-19 safety procedures in the reopening and resuming of tourism operation, and

- The execution of the safety procedures for family vacationers.

This study hopes to fill the possible gap(s) and also to enhance the understanding in managing this harmful and contagious pandemic for risk management. This study is also seen as beneficial to vacationing families so as to reduce travel anxiety.

\section{Literature Review}

\section{Family Vacation}

Family tourists hold a large proportion of the tourism market for many destinations, especially through domestic tourism (Schänzel \& Yeoman, 2014; Backer \& King, 2017). A family vacation is leisure travel, away from home for more than one day, that is undertaken by a family group, which is defined with as at least one child and one adult (Schänzel et al., 2005). Among the outstanding motives for families taking a vacation are to be together, to enhance the bond among participating family members (Schänzel \& Lynch, 2016; Habibah et al., 2015) and learning opportunities for children (Park et al., 2020; Lehto et al., 2017). Moreover, the outcome of a family vacation is usually associated with family values (Schänzel \& Yeoman, 2015) that may help shape the minds of the future adults (Whittington, 2014).

Families on vacation enjoy various forms of transportation, accommodation categories, a variety of foods and beverages, an assortment of attractions, entertainment, and other activities in the tourism offerings (Goeldner \& Ritchie, 2012), which could stimulate happiness and life satisfaction with their family members and also their social life (Kay Smith \& Diekmann, 2017). The activities commonly enjoyed by the family group during a vacation include beach activities (Habibah et al., 2019) for the whole family and/or shopping activities for the mothers (Barlés-Arizón et al., 2013). 
Sadly, the COVID-19 pandemic led to a decreased in travel demands as it creates anxiety and the lockdown measures deter them from travelling to tourist destinations. This situation also caused a decreased in the price of tourism products (Abu Bakar \& Rosbi, 2020). Restaurant and hospitality businesses dropped with loss of income and were unable to retain employees (Dube et al., 2020). Cruises experience a devastating decline (Gössling et al., 2020). Airline and hotel workers were advised to take unpaid leave, pay cut and were terminated from service due to the massive drop in tourism demand (Karim et al., 2020). The potential drop in international tourism economy ranges from 60 to 80 percent (OECD, 2020).

\section{COVID-19 Pandemic and its Impact on Tourism}

COVID-19 is the acronym for "coronavirus disease 2019" that was identified from a novel coronavirus (CoV), which was first discovered in Wuhan, China, before the sporadic spread to the rest of the world (Cascella et al., 2020). COVID-19 affects the respiratory tract and the symptoms are considered as similar to severe acute respiratory syndrome (SARS) and Middle East respiratory syndrome (MERS) (Sohrabi et al., 2020) but with greater infectivity (Peeri et al., 2020).

The delays in disease identification lead to a greater spread of the virus (Lee, 2020). COVID19 can spread among individuals who are in close contact from infected individuals through coughing, sneezing, talking via droplets from their mouth or nose. The infected individuals may not exhibit any symptom and may spread the virus prior to knowing that they are confirmed positive COVID-19 cases. Thus, physical or social distancing of at least six feet away is crucial (CDC, 2020).

To limit local COVID-19 transmission, many countries enforced travel bans as a means of reducing or prohibiting COVID-19 import cases as compared to travel quarantine, which only delays the contagion effect (Chinazzi et al., 2020). The covid pandemic has a high negative impact on the tourism industry in Malaysia, particularly the airline and hotel sectors. For the hotel sector, 170,084 hotel room bookings between 11 January 2020 till 16 March 2020 had been cancelled with revenue loss of RM68,190, 364. This loss is directly attributable to the COVID-19 pandemic (Lee et al., 2021). On a global basis, tourism receipts are not expected to recover to 2019 levels until 2023. Global tourist arrivals for the first half of 2020 fell by more than $65 \%$ with a near halt since April (Behsudi, 2020).

\section{Preventive Behaviour on COVID-19 Risk}

COVID-19 is now worldwide public enemy number one (WHO, 2020; Lee, 2020). The pandemic war requires that the battle requires a societal behavioural shift (Albzeirat et al., 2020). In severe COVID-19 outbreaks, the constructs of health belief model (HBM) can be used as predictors of preventive behaviours to assist in identifying the risks and taking the necessary actions towards better health behaviour (Barakat \& Kasemy, 2020). It is understood that the complex nature of the tourism industry inherently encompasses a complicated process in enjoying a vacation with underlying risks and uncertainties (Quintal et al., 2010). In forecasting tourists' health hazard preventive behaviour and travelling satisfaction, Huang et al., (2020) utilized HBM to explore the health-related issues from a tourism perspective.

HBM is a social psychological behavioural change model that was introduced in the 1950 s by the Public Health Service to explain and predict health-related behaviours. Although there is 
difficulty in tracing the historical development of the framework, the model was extensively used in health research to prevent (not to treat) the disease (Rosenstock, 1974). The theoretical guideline of HBM was also being referred to in other fields of studies, such as in tourism (Huang et al., 2020) and communication (Jones et al., 2015) in predicting and identifying tourists' health risk preventive behaviour.

The main constructs in HBM include six perceptions of perceived susceptibility; perceived severity; perceived benefits; perceived barriers; cues to action; and self-efficacy (Rosenstock et al., 1988). Amongst the constructs, the perceived barrier is the most powerful dimension of HBM since the individuals will evaluate the barriers and problems they might encounter when adopting a new behaviour. In contrast, excessive barriers, however, can create obstacles and prevent the beginning of desired health behaviours (Barakat \& Kasemy, 2020; Jones et al., 2015; Rosenstock et al., 1988).

\section{Global, Local, and Sectoral Preventive Measures}

In combating and breaking the COVID-19 infection chain, World Health Organisation (WHO), which acts as the international body governing the world's health and safety issues, takes the responsibility to disseminate information on COVID-19 precautions. They are simple, yet critical to be implemented, which include (i) frequent hands' cleaning using soap or alcoholbased rub; (ii) elbow is used to cover cough and sneeze, and thereafter cleansed; (iii) avoiding touching the eyes, nose and mouth; and (iv) keeping a one-metre away physical distancing from others who are not from your household. WHO also advises people to limit time at social gatherings or any crowded places and every touched surface needs to be cleaned as well as disinfected frequently (WHO, 2020).

In Malaysia, the Ministry of Health Malaysia (MOH), which is responsible on national healthrelated issues, heavily promotes the "stay at home", "practice 3W", "avoid 3C" and follow "S.O.P" campaigns on a nationwide basis. The "stay at home" campaign encourages people to keep isolating by being at home and to avoid unnecessary outings. The "practice $3 \mathrm{~W}$ " campaign encompasses the washing of hands, wearing a face mask and heeding COVID-19 warnings. Through "avoid 3C" campaign, the $\mathrm{MOH}$ advised the nation to avoid crowded areas, confined places and close conversations. Meanwhile, the acronym of "S.O.P" campaign stands for 'syarat' or rule (follow the movement control rules), 'orang' or person (protect the vulnerable groups and symptomatic persons requiring immediate medical examination), and 'penjarakan' or physical distancing (a minimum of metre distancing). These practices under the 'new norm' were urged to be prioritised in all aspects of daily activities during the COVID19 pandemic (Director-General of Health Malaysia, 2020).

The success of the COVID-19 campaigns' dissemination amongst Malaysians was verified in a study on knowledge, attitudes and practices towards COVID-19, which showed that Malaysians held positive attitudes while taking the necessary precautions. Above $80 \%$ of the respondents said that they avoided crowds and practised hand hygiene. However, $48.8 \%$ of the respondents admitted not wearing a face mask (Azlan et al., 2020). However, wearing a face mask was proven to be crucial in controlling COVID-19 spread by reducing the quantity of emission of infected respiratory droplets from an infected person (Cheng et al., 2020). This research was conducted from March 27 to April 3, 2020 during the first phase of the 
movement control order whereas masking was mandatory in public areas only from August 1, 2020 (codeblue.galancentre.org, 2020).

On top of the local and global precautionary advice, the guidelines for COVID-19 preventive measures at the sectoral level are more comprehensive and denoted all aspects for the sector reopening. To avoid harmful incidents and reduce hotel stay anxiety, Malaysian Association of Hotels (MAH) had taken serious actions by working with the local tourism authorityMinistry of Tourism, Arts and Culture (MOTAC) in producing Clean and Safe Malaysia Hotel Certification Guidelines. The guidelines highlight general cleaning, human resource management, third-party and other resource management and hotel guests management (MAH, 2020). In addition,, MOTAC also developed the industry guidelines for all the tourism sub-sectors with the supervision of the $\mathrm{MOH}$, which was eventually published online $(\mathrm{MOH}$, 2020).

Kaushal and Srivastava highlighted the challenges of COVID-19 in the tourism and hospitality industry and recommended that future studies incorporate other tourism providers like travel intermediaries, airlines, restaurants, locals at destinations, other accommodation providers and viewpoints from other stakeholders (Kaushal \& Srivastava, 2021).

\section{Methodology}

The current study considers the safety procedures applied by family tourism providers that were guided by national and international health organisations. The COVID-19 pandemic situation is considered as novel and thus, the themes surrounding health and safety preventive measures have to be properly delineated. The current published literature surrounding COVID-19 pandemic studies, official government websites and reports from both local and global perspectives were reviewed. The framework of the study is derived from WHO as a worldwide health advisory organisation, Malaysia's health ministry and Malaysia's tourism authorities. The perceived barrier and preventive action dimension of HBM were employed as a conceptual guide to evaluate the health and safety preventive measures for family vacation during the COVID-19 pandemic.

The study areas for this research are Putrajaya and Negri Sembilan, which have popular family tourist destinations in Malaysia. The study employed observation through participatory involvement in family vacation experiences at several popular family tourism products in the above states. Data is collected without posing questions to the observed parties. The observation is done in a natural setting where the activities and behaviours or other items of interest can be noted and recorded. This observational study helps the researcher to be deeply involved and understand the nuances in the field of interest (Sekaran \& Bougie, 2016).

The physical proximity of the destinations with an estimation of one to two-hour drive from the capital city of Kuala Lumpur make these destinations to be popular amongst urban dwellers, especially family tourists for weekend getaways. The natural seascape cum landscape of Port Dickson, Negeri Sembilan, that is surrounded with beautiful beaches for family picnics and water activities, has made the destination to be a favourite option for a family vacation. Putrajaya was included in the study as it is a federal administrative centre that is surrounded with government complexes, where the implementation of COVID-19 
health and safety guidelines within the area are strictly monitored, and thus, is a useful reference perspective.

The field work took place on weekends during the early two months of RMCO from mid of June 2020 to mid of August 2020. The family tourism products consist of accommodations, restaurants and attractions (or activities) were accessed to obtain information on the implemented safety procedures to prevent the transmission of COVID-19. The results of the study are presented in two phases. The first phase reveals the safety procedures practised by tourism providers from the family tourism experience perspectives. Meanwhile, the second phase of the study analyses the implementation of safety procedures based on tourism products consumed by the family vacationers.

Tourism products in this study refer to three elements of accommodation; food and beverage and attractions (or activities) based on the classifications of (Goeldner \& Ritchie, 2012; Fletcher, 2017). The attractions in this study include shopping, beach, swimming pool and boating as a tourism transportation. Although transportation (referring to the public use) is considered as an important means of travel, it was excluded from this discussion due to the fear and anxiety of travelling on public transport during COVID-19 pandemic (Shah et al., 2020). In addition, public transport is seen as less relevant for domestic tourism activities, specifically in the context of travel to proximate destinations. Therefore, the safety aspect of public transport is excluded from this study. As such, the aspect of transportation covered in this study is limited to those related to family tourist attractions for recreational activities. The findings and discussion are covered in the following section.

\section{Findings and Discussion}

Phase One

\section{Tourism Operational Procedures in the COVID-19 Pandemic}

The observation on safety procedures implemented in family vacation offerings during RMCO of COVID-19 pandemic revealed that the advice and guidelines from WHO as well as local authorities were followed by both parties-family tourists and tourism providers. The following figure (see Figure 1) illustrates the operational scopes of safety procedures in tourism reopening during COVID-19 pandemic.

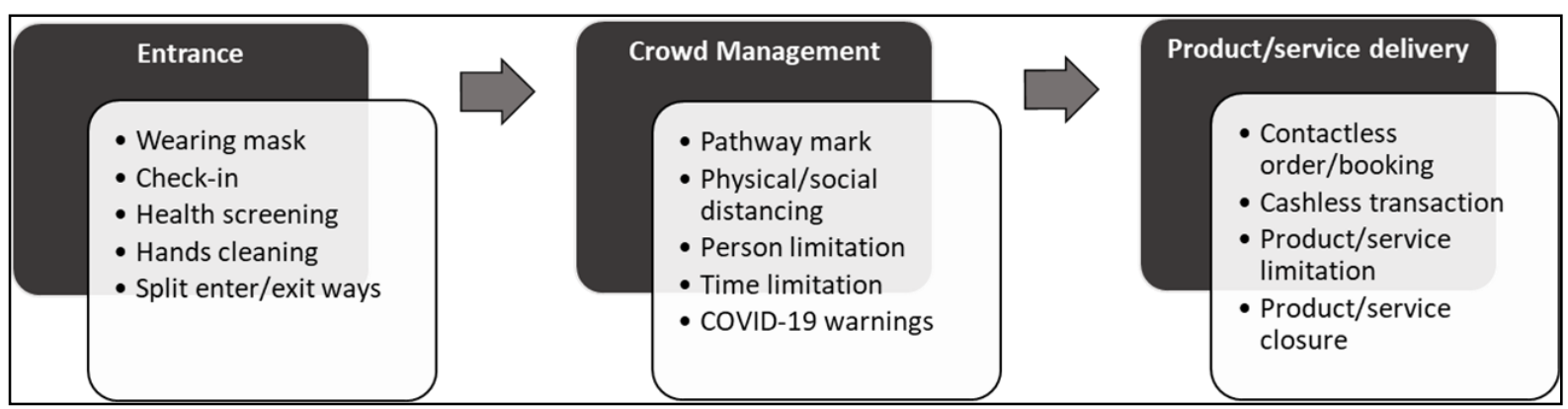

Figure 1: Safe operating procedures in the tourism reopening during COVID-19 pandemic

\section{Entrance}

Upon arrival at any tourism premises, all participating family members are required to wear a mask or mouth and nose cover. Those coming without a mask will not be allowed to enter the premises. Prior to entry, check-in is compulsory to provide personal details of all 
participating family members for contact tracing purposes. The personal information can be done by scanning MySejahtera QR (Quick Response) code using a mobile application installed in their mobile phone or by filling up the visitation record book. For those using MySejahtera mobile application, a representative can perform the check-in on behalf of the family members by ticking the names of the participating family members registered in MySejahtera.

Following suit, health screening of all family members is conducted via checking body temperature. If the body temperature reaches 37.5 degree Celsius or above, entry will be denied. The last practice prior to entering the premises is sanitising the hands with an alcoholbased disinfectant. After full compliance to all the entry procedures, the guests can enter the premises through a designated pathway. The designated doors specified for entrance and exit of the premises are guarded by safety cum security personnel to ensure the health and safety precautions are fully adopted.

The provision of the visitation record book, body temperature scanner and hand sanitiser(s) were undertaken by the management of the premises. However, some families also brought along their personal hand sanitiser(s) during vacation. However, the tourism premises did not provide masks for the visitors but some premises do provide them at a cost.

\section{Crowd Management}

In terms of crowd management procedures, tourism providers marked the pathway with a safe physical distancing consideration. Visitors need to follow the set directions of physical signages located on pylon signs or walls or tape markings on floors to facilitate entry, movement within a particular area and also to exit the premises. At any area where a queue is expected, a one metre physical distancing measure was marked on the floor.

In ensuring the avoidance of crowding, some tourism providers limit the number of visitors for a particular venue, for example a restaurant, at any point in time depending on the spatiality of the said venue. As a consequence, guests may not be able to enter as a family unit simultaneously when the maximum number of in-house visitors is reached for a particular venue. If such a situation were to arise, some of the family members would have to queue awhile prior to joining the other family members. For some tourism providers, instead of limiting the number of in-house visitors, time limitation is applied per in-house visitor to avoid long queuing. From time to time, announcements of COVID-19 warnings were broadcasted at the premises to constantly remind on the covid 19 hazard.

\section{Product cum Service Delivery}

Tourism sector reopening during COVID-19 pandemic also exhibits some product cum service adjustments to comply with the safety requirements. Contactless transactions were heavily promoted and applied extensively throughout purchase experiences. Hotel bookings, meal orderings and ticketing, for instance, were made available virtually either via online or phone call. Payments for the purchase of family vacation products cum services can be conducted online to minimise face to face interaction and long queueing. Some premises limit the product cum service offerings in their current deliveries while other premises temporarily halted certain offerings in accordance to government guidelines. 
Above all, the adjustments taken are in compliance with the guidelines and Standard Operating Procedures (SOP) from the local authorities, MOH, MOTAC, MAH, MKN (National Security Council Malaysia) and KPDNKHEP (Ministry of Domestic Trade and Consumer Affair). The established SOP in tourism offerings were then employed to evaluate the family vacation products. The analysis of COVID-19 SOP implementation will be discussed in the next section.

\section{Phase Two}

\section{COVID-19 Preventive Implementation for Family Vacation Products}

The observed SOP implementation towards preventive behaviours of COVID-19 pandemic for each family vacation product were analysed based on three main dimensions, namely entrance procedures, crowd management procedures and product or service delivery procedures. Table 1 shows the analysis of COVID-19 SOP implementation in family vacation products during the early two months of RMCO.

Table 1: SOP for family vacationers visiting tourism offering

\begin{tabular}{|c|c|c|c|c|c|c|c|}
\hline \multirow[t]{3}{*}{ Dimension } & \multirow{3}{*}{$\begin{array}{l}\text { Preventive } \\
\text { procedure }\end{array}$} & \multicolumn{6}{|c|}{ Tourism offering } \\
\hline & & \multirow{2}{*}{$\begin{array}{l}\text { Accomm } \\
\text {-odation }\end{array}$} & \multirow{2}{*}{$\begin{array}{l}\text { Food and } \\
\text { beverage }\end{array}$} & \multicolumn{2}{|c|}{ Attractions } & \multirow[b]{2}{*}{ 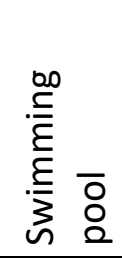 } & \multirow[b]{2}{*}{ 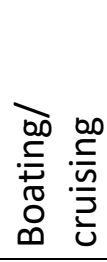 } \\
\hline & & & & $\begin{array}{l}\frac{a}{2} \\
\frac{0}{\circ} \\
\frac{0}{0} \\
\frac{0}{n}\end{array}$ & 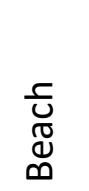 & & \\
\hline \multirow[t]{5}{*}{ Entrance } & Health screening & $\checkmark$ & $\checkmark$ & $\checkmark$ & $x$ & $\checkmark$ & $\checkmark$ \\
\hline & Check-in & $\checkmark$ & $\checkmark$ & $\checkmark$ & $x$ & $\checkmark$ & $\checkmark$ \\
\hline & Hands cleaning & $\checkmark$ & $\checkmark$ & $\checkmark$ & $x$ & $\checkmark$ & $\checkmark$ \\
\hline & Wearing mask & $\checkmark$ & $\checkmark *$ & $\checkmark$ & $\checkmark *$ & $\checkmark *$ & $\checkmark$ \\
\hline & $\begin{array}{l}\text { Split enter/exit } \\
\text { ways }\end{array}$ & $\checkmark$ & $\checkmark$ & $\checkmark$ & $x$ & $\checkmark$ & $\checkmark$ \\
\hline \multirow{5}{*}{$\begin{array}{l}\text { Crowd } \\
\text { managemen } \\
\mathrm{t}\end{array}$} & Pathway marks & $\checkmark$ & $\checkmark$ & $\checkmark$ & $x$ & $\checkmark$ & $\checkmark$ \\
\hline & $\begin{array}{l}\text { Physical } \\
\text { distancing } \\
\text { marks }\end{array}$ & $\checkmark$ & $\checkmark$ & $\checkmark$ & $x$ & $\checkmark$ & $\checkmark$ \\
\hline & Person limitation & $x$ & $\checkmark$ & $\checkmark$ & $x$ & $\checkmark$ & $\checkmark$ \\
\hline & Time limitation & $x$ & $\checkmark$ & $\checkmark$ & $x$ & $\checkmark$ & $x$ \\
\hline & $\begin{array}{l}\text { COVID-19 } \\
\text { warnings }\end{array}$ & $\checkmark$ & $\checkmark$ & $\checkmark$ & $x$ & $\checkmark$ & $\checkmark$ \\
\hline \multirow[t]{4}{*}{$\begin{array}{c}\text { Product/service } \\
\text { delivery }\end{array}$} & $\begin{array}{l}\text { Contactless } \\
\text { order/booking }\end{array}$ & $\checkmark$ & $\checkmark$ & $x$ & $x$ & $x$ & $x$ \\
\hline & $\begin{array}{l}\text { Cashless } \\
\text { transaction }\end{array}$ & $\checkmark$ & $\checkmark$ & $\checkmark$ & $x$ & $\checkmark$ & $x$ \\
\hline & $\begin{array}{l}\text { Product/service } \\
\text { limitation }\end{array}$ & $\checkmark$ & $\checkmark$ & $\checkmark$ & $x$ & $x$ & $x$ \\
\hline & $\begin{array}{l}\text { Product/service } \\
\text { closure }\end{array}$ & $\checkmark$ & $x$ & $\checkmark$ & $x$ & $\checkmark$ & $x$ \\
\hline
\end{tabular}

Note: $\checkmark$ applied; $\times$ not applied; ${ }^{*}$ exception with condition 


\section{Entrance}

During the sectoral reopening, the number of entrances or access to some premises like a restaurant, shopping mall, swimming pool and boating was reduced for effective monitoring and implementation of COVID-19 SOP. Other entrance procedures in the 'new norm' routines of mask application, check-in procedures, health screening of body temperature and hands disinfection were applied and were made compulsory before entering the premises, except for beaches as there is no monitoring mechanism of such requirements at the venue. During the early phase of RMCO, many beach visitors were found not putting on their mask, until 1st August 2020 where mask wearing was made mandatory in Malaysia. Those who caught breaching the order will be fined RM1,000 according to the Prevention and Control of Infectious Disease Act 1988 (Act 342) (Laws of Malaysia, 2017).

Even though the enforcement of wearing a mask at public places has been announced, the tourists' compliance is still very minimal. Many family tourists were seen to not put on a mask while relaxing on the beach. Nonetheless, as family tourists and other tourists were sitting in individual groups within acceptable distancing from each other, therefore, the situation is seen as harmless. The enforcement to wear a mask at public places like restaurants and swimming pools was a little lax as tourists need to take off their mask prior to their meal or swimming respectively. Family tourists are advised to fold their mask and put it aside when dining. Some premises would provide a plastic bag to put the mask in. Such advice is also applicable for swimmers at swimming pools. Both restaurants and swimming pools require family tourists to wear a mask upon entrance and exit.

\section{Crowd Management}

Crowd management is crucial in avoiding the potential risk of disease transmission while promoting family vacation. Warnings on COVID-19 precautions were displayed at the main entrance and all strategic points within the premises to alert visitors on disease prevention. Moreover, the crowd movement within the premises is in accordance to the pathway markers, including the entry and exit points that were marked separately to avoid any confusion and potential contra flow for a particular pathway. Physical distancing markers were displayed with a one metre distance between each marker at queueing areas. However, there is a different requirement in physical distancing measures at swimming pools, with one to three metres of physical distancing for static activities and between three to five metres of physical distancing for dynamic activities.

According to physical distancing and spatiality, a limited number of in-house visitors was predetermined by the tourism providers. Premises that implemented such a procedure include restaurants, shopping malls, swimming pools and boating activities. In addition, every visitor who is permitted to enter a premises was also given a limited duration to indulge themselves at restaurants, shopping centres and swimming pools. At the swimming pool, family tourists were given 30 minutes to enjoy pool activities per family group. Meanwhile, the duration for boat ride is subjected to normal operations.

Nevertheless, all COVID-19 precautions imposed on crowd safety as mentioned above do not apply to the beach area. Family vacation activities at the beach are considered as the most relaxing and less rigid as compared to other tourism offerings. Family members were seen to 
indulge themselves in water and beach activities without having strict boundaries for compliance to COVID-19 procedures.

\section{Product cum Service Delivery}

The family vacation experience during COVID-19 also witnessed alterations in the product cum service delivery aspects of the tourism offerings. There are a few on-premises or in-house procedures that must be followed by family tourists. The management of tourism products also highly advocate the contactless form of transactions to avoid the potential risk of COVID19. For family vacation, hotel bookings and meal orders are available virtually. Online hotel booking is common in the tourism industry. However, for restaurants, the introduction of online meals ordering has flourished during the COVID-19 pandemic. Although family tourists can still enjoy dining in, some restaurants do encourage meals ordering via their website using the provided QR code at every dining table or via self-ordering system kiosks. To complete the transactions, cashless payment is also made available and is widely applied at hotels, shopping malls and restaurants. Both virtual order and payments are seen as helpful in reducing the risk of potential disease transmission while enjoying a family vacation.

Some tourism providers applied delivery adjustments during COVID-19 pandemic by limiting their offerings. To avoid the risk of disease transmission via fabric-based products, a few clothing and apparels premises at shopping malls do not allow cloth fittings during the early phase of RMCO. At some shoe departments, shoes fitting is only permitted with the use of socks either with the customer's own socks or socks provided by the management. However, in the second month of RMCO, this procedure was slowly discarded. For hotels, with the best hygiene in mind, linens such as colourful throw pillows, bed runners and fluffy bathrobes were temporarily removed from the guest rooms.

Moreover, the restaurants' meal delivery also faced some amendments in their product cum service delivery, inclusive of in-house restaurants at hotels. The self-service method on buffet meal was altered into the serve-service method. Staff serving meals to visitors, were seen wearing hand gloves for hygiene purposes. The choices for the buffet menu were also reduced to a limited selection. For hotel guests, especially for families with dependent children, room service would be a better alternative to enjoy their meals.

During reopening of the tourism sector, activities for children in family vacation are somewhat limited since not all tourism products cum services resumed operation. The in-house waterbased facility, such as swimming pools (including hotel swimming pool), indoor games and fun activity sections at shopping malls remained closed during the early phase of RMCO until circumstances allowed it to be reopened commencing from July 1, 2020.

On an overall basis, it can be concluded that the precautions taken during COVID-19 pandemic are a necessity. The enforcements, actions SOP and policies taken by the authorities were at par with global standards. Tourism providers were delighted to welcome family tourists during the reopening by offering tourism products at attractive costs whilst the security and hygiene protocols in combating the disease were enhanced. Thus, families can travel worryfree and indulge themselves in the tourism experience while strictly maintaining the 'new norms' during the COVID-19 pandemic. 


\section{Conclusion}

This study underlined the safety procedural guidelines and implementations in Malaysia's tourism industry during the RMCO of COVID-19 pandemic. The focus of the study is to analyse and evaluate the COVID-19 preventive measures during the reopening of the tourism sector for family tourism offerings. The three major areas of preventive measures undertaken by tourism providers which were covered in this study were entrance, crowd management and product cum service delivery. Based on the analysis of COVID-19 SOP implementation for family vacation products, it was found that the beach offers the greatest flexibility for the families to enjoy their vacation during COVID-19 pandemic as they have greater freedom.

As family tourists usually travel with young children, such information can provide the family with an ideal family vacation within the bounds of safety. It is also an acknowledgement that the tourism providers and practitioners have taken the necessary preventive actions to rejuvenate the tourism sector by preventing the chain of COVID 19 infection.

Due to the limitations of time and distance, the study was limited to a few family tourism destinations which were the favourite options amongst urban dwellers residing in the capital city of Malaysia. This study did not cover other tourism offerings at other localities, which may be guided by different norms and safety concern respectively. The tourism offerings and associated SOP mentioned in this study encompass the experiences from the standpoint of family tourism and might not fully reflect other tourism offerings and related tourist markets.

In the global pandemic, individuals become more collectivistic and as a result, tourists might opt for domestic vacation rather than international destinations (Zenker \& Kock, 2020). Hence, for future family tourism studies, researchers can examine the perception and opinion of families in identifying the motivation and deterrence in taking a family vacation during the pandemic. This information is valuable for the tourism marketers in strategising their marketing efforts in taking the necessary actions by meeting the demands and gaining the confidence of families in taking a vacation.

\section{Acknowledgments}

The APC was funded by the grant of 'Geran Penyelidikan Khas Top Down UKM: Wabak COVID19' number GPK-C19-2020-014 and 'Geran Kepentingan Pemeliharaan Khazanah Asli ke arah Pelancongan Lestari: Kes Kajian di Gunung Kinabalu, Sabah, Malaysia' number IDE-2018-006. This research was supported by the Ministry of Higher Education Malaysia and Universiti Teknologi MARA via SLAB scholarship.

\section{References}

Abu Bakar, N., \& Rosbi, S. (2020). Effect of Coronavirus disease (COVID-19) to tourism industry. International Journal of Advanced Engineering Research and Science, 7(4), 189193. https://doi.org/10.22161/ijaers.74.23

Albzeirat, M. K., Al-Tarawneh, M. S., Khalid, N., Zulkepli, N. N., \& Islam, D. M. Z. (2020). COVID19 story the unknown killer and future studies. International Journal of Multidisiplinary Sceinces and Advanced Technology, Special Issue Covid-19, 1(1), 1-18.

Azlan, A. A., Hamzah, M. R., Sern, T. J., Ayub, S. H., \& Mohamad, E. (2020). Public knowledge, attitudes and practices towards COVID-19: A cross-sectional study in Malaysia. PLoS ONE, 15(5), 1-15. https://doi.org/10.1371/journal.pone.0233668 
Backer, E., \& King, B. (2017). VFR traveller demographics: The social tourism dimension. Journal of Vacation Marketing, 23(3), 191-204.

Barakat, A. M., \& Kasemy, Z. A. (2020). Preventive health behaviours during coronavirus disease 2019 pandemic based on health belief model among Egyptians. Middle East Current Psychiatry, 27(43), 1-9. https://doi.org/10.1186/s43045-020-00051-y

Barlés-Arizón, M. J., Fraj-Andrés, E., \& Martínez-Salinas, E. (2013). Family Vacation Decision Making: The Role of Woman. Journal of Travel and Tourism Marketing, 30(8), 873-890. https://doi.org/10.1080/10548408.2013.835681

Behsudi, A. (2020). Tourism-dependent economies are among those harmed the most by the pandemic. Finance and Development, December 2020,36-39.

https://www.imf.org/external/pubs/ft/fandd/2020/12/impact-of-the-pandemic-ontourism-behsudi.htm

Cascella, M., Rajnik, M., Cuomo, A., Dulebohn, S. C., \& Di Napoli, R. (2020). Features, Evaluation and Treatment Coronavirus (COVID-19). In StatPearls [internet]. StatPearls Publishing. http://www.ncbi.nlm.nih.gov/pubmed/32150360

CDC. (2020). Social Distancing. U.S. Department of Health \& Human Services. https://www.cdc.gov/coronavirus/2019-ncov/prevent-getting-sick/socialdistancing.html

Che Omar, A. R., Ishak, S., \& Jusoh, M. A. (2020). The impact of Covid-19 Movement Control Order on SMEs' businesses and survival strategies. Malaysian Journal of Society and Space, 16(2), 139-150. https://doi.org/10.17576/geo-2020-1602-11

Cheng, V. C. C., Wong, S. C., Chuang, V. W. M., So, S. Y. C., Chen, J. H. K., Sridhar, S., To, K. K. W., Chan, J. F. W., Hung, I. F. N., Ho, P. L., \& Yuen, K. Y. (2020). The role of communitywide wearing of face mask for control of coronavirus disease 2019 (COVID-19) epidemic due to SARS-CoV-2. Journal of Infection, 81(1), 107-114.

https://doi.org/10.1016/j.jinf.2020.04.024

Chinazzi, M., Davis, J. T., Ajelli, M., Gioannini, C., Litvinova, M., Merler, S., Pastore y Piontti, A., Mu, K., Rossi, L., Sun, K., Viboud, C., Xiong, X., Yu, H., Elizabeth Halloran, M., Longini, I. M., \& Vespignani, A. (2020). The effect of travel restrictions on the spread of the 2019 novel coronavirus (COVID-19) outbreak. Science, 368(6489), 395-400. https://doi.org/10.1126/science.aba9757

Code Blue. (2020). Starting Aug 1, Masks Mandatory in Public Areas with Max RM1,000 Fine. https://codeblue.galancentre.org/2020/07/23/starting-aug-1-masks-mandatory-inpublic-areas-withrm1000-fine/

Director-General of Health Malaysia. (2020). Kenyataan Akhbar KPK 18 May 2020 - Situasi Semasa Jangkitan Penyakit di Malaysia. Ministry of Health Malaysia. Retrieved 26 August 2020 from https://kpkesihatan.com/2020/06/14/kenyataan-akhbar-kpk-14-jun-2020situasi-semasa-jangkitan-penyakit-coronavirus-2019-covid-19-di-malaysia/

Dube, K., Nhamo, G., \& Chikodzi, D. (2020). COVID-19 cripples global restaurant and hospitality industry. Current Issues in Tourism, 1-4. https://doi.org/10.1080/13683500.2020.1773416

Elengoe, A. (2020). COVID-19 outbreak in Malaysia. Osong Public Health and Research Perspectives, 11(3), 93-100. https://doi.org/10.24171/j.phrp.2020.11.3.08

Fletcher, J., Fyall, A., Gilbert, D., \& Wanhill, S. (2017). Tourism: Principles and practice (6th ed., Vol. 32, Issue April). UK: Pearson.

Goeldner, C., \& Ritchie, B. (2012). Tourism: Principles, Practices, Philosophies (12th ed.). USA: John Wiley \& Sons, Inc. 
Gössling, S., Scott, D., \& Hall, C. M. (2020). Pandemics, tourism and global change: a rapid assessment of COVID-19. Journal of Sustainable Tourism, 29(1), 1-20.

https://doi.org/10.1080/09669582.2020.1758708

Habibah, A., Hamzah, J., Er, A. C., Buang, A., \& Selvadurai, S. (2015). Appraisal of familyfriendly tourism in Malaysia. Tourismos, 10(1), 37-62.

Habibah, Ahmad, Hamzah, J., Noradila, A., Kadaruddin, A., Nurul Fadhiah, M., \& Mohd Fuad, M. J. (2019). Pantai pelancongan mesra keluarga dan tuntutan persekitaran fizikal semulajadi daripada lensa pelancong tempatan. Malaysian Journal of Society and Space, 15(4), 321-335. https://doi.org/10.17576/geo-2019-1504-23

Huang, X., Dai, S., \& Xu, H. (2020). Predicting tourists' health risk preventive behaviour and travelling satisfaction in Tibet: Combining the theory of planned behaviour and health belief model. Tourism Management Perspectives, 33, 100589. https://doi.org/10.1016/j.tmp.2019.100589

Jones, C. L., Jensen, J. D., Scherr, C. L., Brown, N. R., Christy, K., \& Weaver, J. (2015). The Health Belief Model as an Explanatory Framework in Communication Research: Exploring Parallel, Serial, and Moderated Mediation. Health Communication, 30(6), 566-576. https://doi.org/10.1080/10410236.2013.873363

Karim, W., Haque, A., Anis, Z., \& Ulfy, M. A. (2020). The Movement Control Order (MCO) for COVID-19 Crisis and its Impact on Tourism and Hospitality Sector in Malaysia. International Tourism and Hospitality Journal, 3(2), 1-7. https://doi.org/10.37227/ithj2020-02-09

Kaushal, V., \& Srivastava, S. (2021). Hospitality and tourism industry amid COVID-19 pandemic: Perspectives on challenges and learnings from India. International Journal of Hospitality Management, 92. 102707. https://doi.org/10.1016/j.ijhm.2020.102707

Kay Smith, M., \& Diekmann, A. (2017). Tourism and wellbeing. Annals of Tourism Research, 66, 1-13. https://doi.org/10.1016/j.annals.2017.05.006

Khor, V., Arunasalam, A., Azli, S., Khairul-asri, M. G., \& Fahmy, O. (2020). Experience from Malaysia During the COVID-19 Movement Control Order. Urology, 141, 179-180. https://doi.org/10.1016/j.urology.2020.04.070

Laws of Malaysia. (2017). Prevention and Control of Infectious Diseases Act 1988.

Lee, A. (2020). Wuhan novel coronavirus (COVID-19): why global control is challenging? Public Health, 179, A1. https://doi.org/10.1016/j.puhe.2020.02.001

Lee, P.F., Chin, M.Y., Tan, K.L. and Phuah, K.T. (2021). The impact of COVID-19 on tourism industry in Malaysia. Current Issues in Tourism, 24(19), 2735-2739.

https://www.tandfonline.com/doi/full/10.1080/13683500.2020.1777951

Lehto, X. Y., Fu, X., Li, H., \& Zhou, L. (2017). Vacation Benefits and Activities: Understanding Chinese Family Travelers. Journal of Hospitality and Tourism Research, 41(3), 301-328. https://doi.org/10.1177/1096348013515921

MAH. (2020). Clean \& Safe Malaysia Hotel Certicification Guidelines (Issue July). Malaysia Association of Hotels.

MOH. (2020). SOP Pembukaan Ekonomi (Kemaskini 03 Jun 2020). http://covid19.moh.gov.my/faqsop/sop-pembukaan-ekonomi-kemaskini-03-jun-2020

OECD. (2020). Tourism Policy Responses to the coronavirus (COVID-19).

Park, S. Y., Pan, B., \& Ahn, J. B. (2020). Family trip and academic achievement in early childhood. Annals of Tourism Research, 80, 102795.

https://doi.org/10.1016/j.annals.2019.102795

Peeri, N. C., Shrestha, N., Rahman, M. S., Zaki, R., Tan, Z., Bibi, S., Baghbanzadeh, M., 
Aghamohammadi, N., Zhang, W., \& Haque, U. (2020). The SARS, MERS and novel coronavirus (COVID-19) epidemics, the newest and biggest global health threats: what lessons have we learned? International Journal of Epidemiology, 49(3), 717-726. https://doi.org/10.1093/ije/dyaa033

Prime Minister Office of Malaysia. (2020). Teks Ucapan Yab Tan Sri Dato' Haji Muhyiddin Bin Haji Mohd Yassin Pelaksanaan Perintah Kawalan Pergerakan Pemulihan (PKPP) 7 Jun 2020 (Ahad) (pp. 1-7). Retrieved 26 August 2020 from https://www.pmo.gov.my

Quintal, V. A., Lee, J. A., \& Soutar, G. N. (2010). Risk, uncertainty and the theory of planned behavior: A tourism example. Tourism Management, 31(6), 797-805. https://doi.org/10.1016/j.tourman.2009.08.006

Rosenstock, I. (1974). Historical Origins of the Health Belief Model. Health Education Monographs, 2(4), 328-335.

Rosenstock, I. M., Strecher, V. J., \& Becker, M. H. (1988). Social Learning Theory and the Health Belief Model. Health Education \& Behavior, 15(2), 175-183. https://doi.org/10.1177/109019818801500203

Schänzel, H. A., \& Yeoman, I. (2014). The future of family tourism. Tourism Recreation Research, 39(3), 343-360. https://doi.org/10.1080/02508281.2014.11087005

Schänzel, H. A., \& Lynch, P. A. (2016). Family perspectives on social hospitality dimensions while on holiday. Tourist Studies, 16(2), 133-150.

https://doi.org/10.1177/1468797615594742

Schänzel, H. A., Smith, K. A., \& Weaver, A. (2005). Family Holidays: A Research Review and Application to New Zealand. Annals of Leisure Research, 8(2-3), 105-123. https://doi.org/10.1080/11745398.2005.10600965

Schänzel, H. A., \& Yeoman, I. (2015). Trends in family tourism. Journal of Tourism Futures, 1(2), 141-147. https://doi.org/10.1108/JTF-12-2014-0006

Sekaran, U., \& Bougie, R. (2016). Research Method for Business: a skill building approach (7th ed.). John Wiley \& Sons, Inc.

Shah, A. U. M., Safri, S. N. A., Thevadas, R., Noordin, N. K., Rahman, A. A., Sekawi, Z., Ideris, A., \& Sultan, M. T. H. (2020). COVID-19 outbreak in Malaysia: Actions taken by the Malaysian government. International Journal of Infectious Diseases, 97, 108-116. https://doi.org/10.1016/j.ijid.2020.05.093

Sohrabi, C., Alsafi, Z., O’Neill, N., Khan, M., Kerwan, A., Al-Jabir, A., losifidis, C., \& Agha, R. (2020). World Health Organization declares global emergency: A review of the 2019 novel coronavirus (COVID-19). International Journal of Surgery, 76(February), 71-76. https://doi.org/10.1016/j.ijsu.2020.02.034

Whittington, A. (2014). Family vacation 2050: Socially and technologically-Driven scenarios of the future of family travel, recreation and tourism. Tourism Recreation Research, 39(3), 379-396. https://doi.org/10.1080/02508281.2014.11087007

WHO. (2020). COVID-19 severity. World Health Organization Western Pasific Region. Retrieved 6 August 2020 from https://www.who.int/westernpacific/emergencies/covid19/information/severity

Zenker, S., \& Kock, F. (2020). The coronavirus pandemic - A critical discussion of a tourism research agenda. Tourism Management, 81, 104164.

https://doi.org/10.1016/j.tourman.2020.104164 